\title{
積層基板構造による小型広帯域コイルの検討
}

\author{
鈴木 洋一朗 ${ }^{* 1, * 4}$, 河野 秀一 ${ }^{* 2}$, 片岡 良平 ${ }^{* 3}$, 木村 友則 ${ }^{* 3}$, 桑野 博喜 ${ }^{* 5}$
}

\section{Study of compact and broad spectrum coil by the laminated substrates structure}

\author{
Youichirou SUZUKI ${ }^{* 1, * 4}$, Shuichi KOUNO ${ }^{* 2}$, Ryohei KATAOKA ${ }^{* 3}$, \\ Tomonori KIMURA $^{* 3}$ and Hiroki KUWANO*5 \\ ${ }^{*_{1},{ }^{* 2}}$ NIPPON SOKEN, INC. 14 Iwaya, Shimohasumi-cho, Nishio-shi, Aichi 445-0012, Japan \\ ${ }^{* 3}$ DENSO CORPORATION 1-1, Showa-cho, Kariya-shi, Aichi 448-8661, Japan \\ ${ }^{* 4, * 5}$ Department of Nanomechanics, School of Engineering, Tohoku University \\ 6-6-01 Aza-Aoba, Aramaki, Aoba-ku, Sendai-shi, Miyagi 980-8579, Japan
}

\section{Received 25 December 2014}

\begin{abstract}
We develop compact and broad spectrum coil for application of the current sensor. We propose the laminated substrates type coil using PALAP (Patterned prepreg Lay up Process) substrates excellent in high frequency characteristics and miniaturization, and we verify that frequency band of $1.2 \mathrm{GHz}$ and thickness of $0.7 \mathrm{~mm}$ could achieve with a prototype.
\end{abstract}

Key words : Current sensor, Broad spectrum, Laminated substrate, PALAP, Electromagnetic induction, Rogowski coil, Car electronics, Energy harvester

\section{1. 緒言}

近年，自動車の電動化が進展し，インバータや DC-DC コンバータ等パワーエレクトロニクス製品の研究開発 が活発に進められている，上記パワーエレクトロニクス製品の開発においては，更なる小型，軽量化を実現する ため，スイッチング損失低滅に向けた高速スイッチング技術がキ一技術となっている．スイッチング素子におい ても，従来の IGBT や MOS に比べ高速スイッチングが期待できる GaN，SiC，SJ-MOS 等次世代素子の開発が進 められている.

しかしながら，スイッチング速度向上の背反として，高周波リンギングの発生によるノイズの増大を招くこと となり，高効率化と低ノイズ化を両立できるスイッチング技術の開発が求められている.

上記高効率および低ノイズスイッチング技術の開発においては，スイッチング時に発生する高周波リンギング 電流を高精度に計測評価する技術，また将来的には上記電流をセンシングしスイッチング制御に反映することも 必要となってくる，パワエレ回路の大電流を捉える方法として， ロゴスキーコイル式の電流センサが提案されて いる（石山，2002）（岡田，井上，2002）。しかしながら，次世代の高速スイッチング素子においては，発生する リンギングの周波数成分も高周波化しており，周波数帯域が十分に得られないことが課題となっている（Oates, et al., 2002）（Qing, et al., 2006）。本研究では，リンギング電流を高精度に計測することを目的とし，市販の広帯域電 流プローブ（ピアソン社製，2877）では周波数帯域が $200 \mathrm{MHz}$ までであるのに対し，将来のスイッチングデバイ スの高速化に向けて，1GHz 以上の広帯域化を目指す。また，パワエレ回路では大電流を流寸ため，回路配線が 持つインダクタンス成分が無視できず，極力短く配線設計することが必要となる．しかしながら，電流センサを 挿入するためには一定の配線長が必要となり，そのサイズが大きな場合には，センサ挿入用の追加配線によりイ

No.14-00696 [DOI: 10.1299/transjsme.14-00696], J-STAGE Advance Publication date : 6 July, 2015

${ }^{* 1}$ 正員, (株) 日本自動車部品総合研究所（广444-0012 愛知県西尾市下羽角町岩谷 14）

*2 (株) 日本自動車部品総合研究所

*3 （株）デンソー（テ448-8661 愛知県刈谷市昭和町 1-1）

*4 正員，東北大学大学院工学研究科（厂980-8579 宮城県仙台市青葉区荒巻字青葉 6-6-01 )

*5 正員, フェロー, 東北大学大学院工学研究科

E-mail of corresponding author: youichirou_suzuki@soken1.denso.co.jp 
ンダクタンス成分の増大を招き，実回路と異なる高周波電流を計測評価せざるを得ない．また，センシング素子 として回路と一体に組み込む場合にも，大型化することが課題となっている.

上記センサの課題に対して, 計測周波数の広帯域化, 小型化（プローブ厚みの薄型化）の観点から, 積層基板 構造によるコイルの開発に取り組んだ。基板には, 高周波特性に優れており, 且つ薄型化も実現できる PALAP

（Patterned prepreg Lay up Process）基板（片岡他，2005）（Hayashi, et al., 2004）（矢崎他，2005）を用いて積層基板 構造を形成した. また, PALAP 基板は電子部品の内蔵が可能であることから, センサ出力を後処理する回路（増 幅回路や積分回路など）も一体で作りこめるため, 素子, 回路全体を見たときの小型化においても有効である.

本研究では, 電流センサのスペック（周波数帯域 $1 \mathrm{GHz}$ 以上，センサ挿入部 $5 \mathrm{~mm}$ 以下）を満た寸積層基板構造 による小型広帯域コイルを試作し，厚み $0.7 \mathrm{~mm} ，$ 周波数帯域 $1.2 \mathrm{GHz}$ が得られることを検証した.

\section{2. ロゴスキーコイルの構造と原理}

ロゴスキーコイルの構造を図 2 に示寸．ロゴスキーコイルは環状体(通常は空芯)に導体を均一に巻いたコイル と, コイルの中を通って巻き戻される戻り線から構成されるもので，このコイルの内側を貫通する交流電流 I を 磁束変化として検出する (磁束変化を打ち消寸起電力が発生). 上記コイルは外部磁界に対して 1 ターンのループ アンテナとなるが，戻り線を追加することで外部磁界の影響をキャンセルできる特長を持つため，外乱（外部磁 界）の影響を受けず高精度な電流計測が可能となる（伊藤，1967）（木下，1973）。

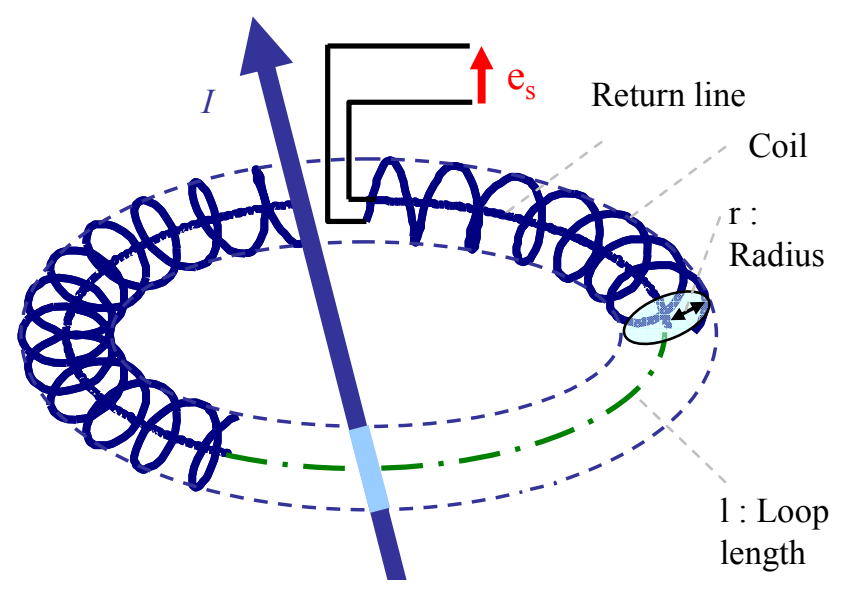

(a) Structure of conventional Rogowski-coil

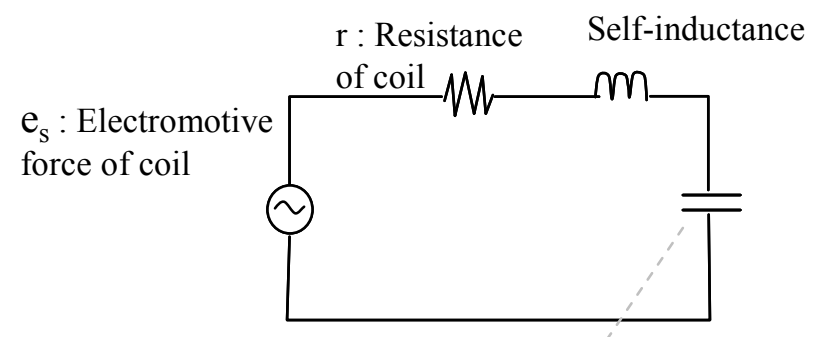

C : Total capacitance, for example between coil and return line and so on

(b) Equivalent circuit of Rogowski-coil

Fig. 1 Conventional Rogowski-coil

$$
\begin{aligned}
& e_{s}=\frac{\pi r^{2} \mu_{0} N}{l} \frac{d I}{d t} \\
& L=\frac{\pi r^{2} \mu_{0} N^{2}}{l} \\
& f_{c}=\frac{1}{2 \pi \sqrt{L C}} \\
& r: \text { コイル半径 }[\mathrm{m}] \\
& \mathrm{N}: \text { コイルの巻き数 } \\
& 1: \text { コイルの周回長 }[\mathrm{m}]
\end{aligned}
$$




$$
\mu_{0}=4 \pi \times 10^{-7}[\mathrm{H} / \mathrm{m}]
$$

図 1 において，ロゴスキーコイルの起電力 $\mathrm{e}_{\mathrm{s}}[\mathrm{V}]$ は，コイルの半径 $r$, 巻き数 $\mathrm{N}$, 周回長 1 とすると式(1)で算 出できる. 電流変化率に比例した起電力が得られ，積分処理することで電流值が求められるが，本論文では積分 処理の具体的な手法については検討の対象外とし， ロゴスキーコイルの広帯域化の検討を行った結果を述べる. またコイルの自己インダクタンス $\mathrm{L}[\mathrm{H}]$ は式(2) で算出できる. 周波数帯域を向上させるためには自己インダクタ ンス L とコイルの寄生容量 Cによって式(3)で算出できる共振周波数 $\mathrm{f}_{\mathrm{c}}[\mathrm{Hz}]$ を上げることが必要である.

\section{3. 積層基板構造による小型広帯域ロゴスキーコイル}

本研究で検討した積層基板型ロゴスキーコイルの構造を図 2 に示寸. 任意の 2 層に基板パターンによって基板 平面方向に放射状のラインを，またこれら 2 層の間の 1 層に同様に円周状のラインを形成し，これらの基板パタ ーンを基板厚み方向にビア接続することでロゴスキーコイルを形成する．また，コイル外側を囲むように外部電 界シールドを形成している．シールド面は上面，底面，外周及び内周の側面に形成するが，コイル内周の側面の シールド面については，コイル内側の電流から発生する磁界を検出できるよう，コイル一周にわたるスリットを 形成している.

また, 本研究では基板に PALAP 基板を用いることを提案する. PALAP 基板の特長として, (1)低誘電率 ( $\varepsilon=3.0$ at $1 \mathrm{MHz} \sim 10 \mathrm{GHz}$ ），低誘電損失（ $\tan \delta=0.003$ at $1 \mathrm{MHz} \sim 75 \mathrm{GHz}$ ）である，(2)基板厚みが極薄（50um/層）であり，また， 熱可塑性樹脂を用いているため可とう性を持つ, (3)連続ビアにより基板厚み方向に導体面が作製可能である, (4) 基板内にコンデンサやダイオードなど回路部品内蔵実装が可能であることが挙げられる. (1), (2)の特長を活かし て積層基板型ロゴスキーコイルの高周波化，薄型化を実現している．また，(3)の特長を活かして基板厚み方向の 外部電界シールド面を形成しており, 外来ノイズの混入を防止し電流センサの精度確保が期待できる. また, (4) の特長を活かして電流センサのアンプ回路等の周辺回路部品を内蔵実装できるため, 周辺回路含めて小型化が期 待できる. よって, 提案する PALAP 基板を用いた積層基板構造のコイルは, 主に広帯域特性と小型化（プローブ 厚みの薄型化）の 2 点で優れており，これを量産に適した低コストな製造方法にて実現することができる.

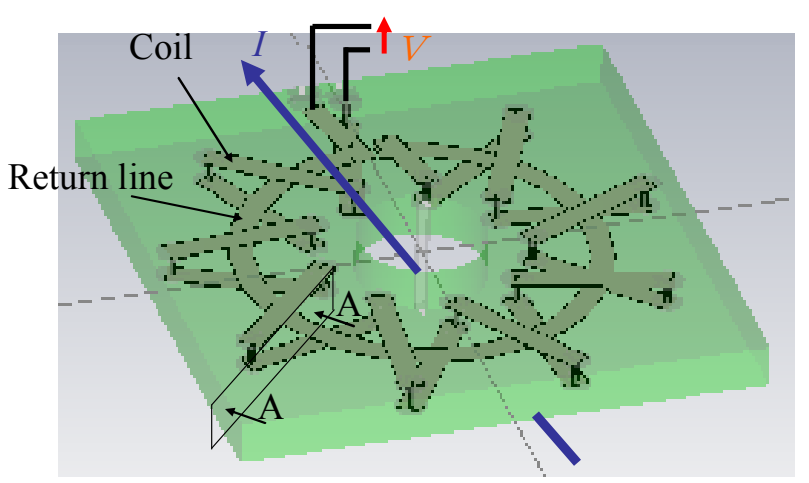

(a) Whole structure

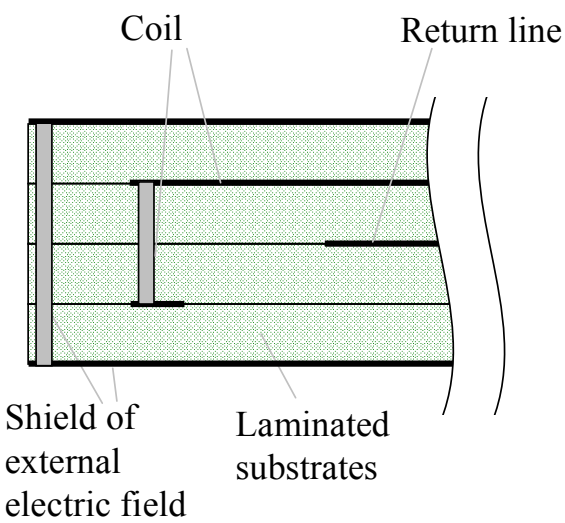

(b) A-A cross section

Fig. 2 The structure of laminated substrates type Rogowski-coil

\section{4. 積層基板型ロゴスキーコイルの設計}

ロゴスキーコイルの高周波化においては，上記の通り自己インダクタンス L と容量 C を低減することが必要と なる. 自己インダクタンス $\mathrm{L}$ の低減については, 巻き数の減少, コイル径の減少, コイル線幅の増大が有効であ 
る. 巻き数及びコイル径の減少については感度の低下が背反となるが，本研究ではパワエレ回路の比較的大電流 の計測を対象としているため許容している. また，容量 Cの低隇については，コイルとシールド面間やコイルと 戻り線間の結合容量が支配的であり，基板厚み方向の結合距離の増大や結合面積(コイル線幅)の減少が有効であ る. 今回のロゴスキーコイルは自己インダクタンス L の低減を目的に, 巻き数を減らしているため, コイルの分 布容量については，上記結合容量に対し十分小さく，影響は無視できると考える.

今回，ロゴスキーコイル全体をPALAP 基板 14 層で厚み $0.7 \mathrm{~mm}$ とし， 1. 結合容量が最小となるようコイルを形 成する層を決定, 2 . 高周波特性が最適となるようコイルの線幅を決定するといった手順でロゴスキーコイルの高 周波化を検討した。

\section{$4 \cdot 1$ コイル形成層の検討}

結合容量 C が最小となり共振周波数を最も向上できるコイル形成層をシミュレーション (CST 社製の MW STUDI0 を解析ソフトとして使用）にて検討した．なお， S パラメータ通過特性（ $S_{21}$ : Port $1 \rightarrow$ Port2）にて周波数特性を評 価しており，上記通過特性が周波数に対して比例関係にある範囲がセンシング可能な帯域となる. シミュレーシ ヨン構成(コイル全体および断面)を図 3,4 に示寸. 図 3 に記載のシミュレーション構成は, 第 5 章の図 8 にあ ネットワークアナライザを用いた 2 ポート測定を模擬した構成（Port1 が $50 \Omega$ 終端させたマイクロストリップラ インに被測定電流を供給する入力ポートに相当, Port2 がロゴスキーコイルの出力ポートに相当し，もう片側は $50 \Omega$ 終端) である.コイル形成層を(a)〜 ( c) の 3 通りとした時の, S パラメータ通過特性 $\left(S_{21}\right)$ のシミュレーショ ン結果を図 5 に示寸。

(a)の構成においては，シールド面とコイル間の距離が近いため，上記間での結合容量 C が大きく，共振点が $1.9 \mathrm{GHz}$ 付近に出ている. (b)の構成においては, シールド面とコイル間の距離が増大し, 共振点が $3 \mathrm{GHz}$ まで向上 している. (c)の構成においては, シールド面とコイル間の距離が更に増大寸るが，一方でコイルと戻り線間の距 離が小さく, 共振点が $1.4 \mathrm{GHz}$ 付近に出ている. これらの結果より, (b) の構成が結合容量を最も小さく, 共振周 波数を向上できる構成と考える.

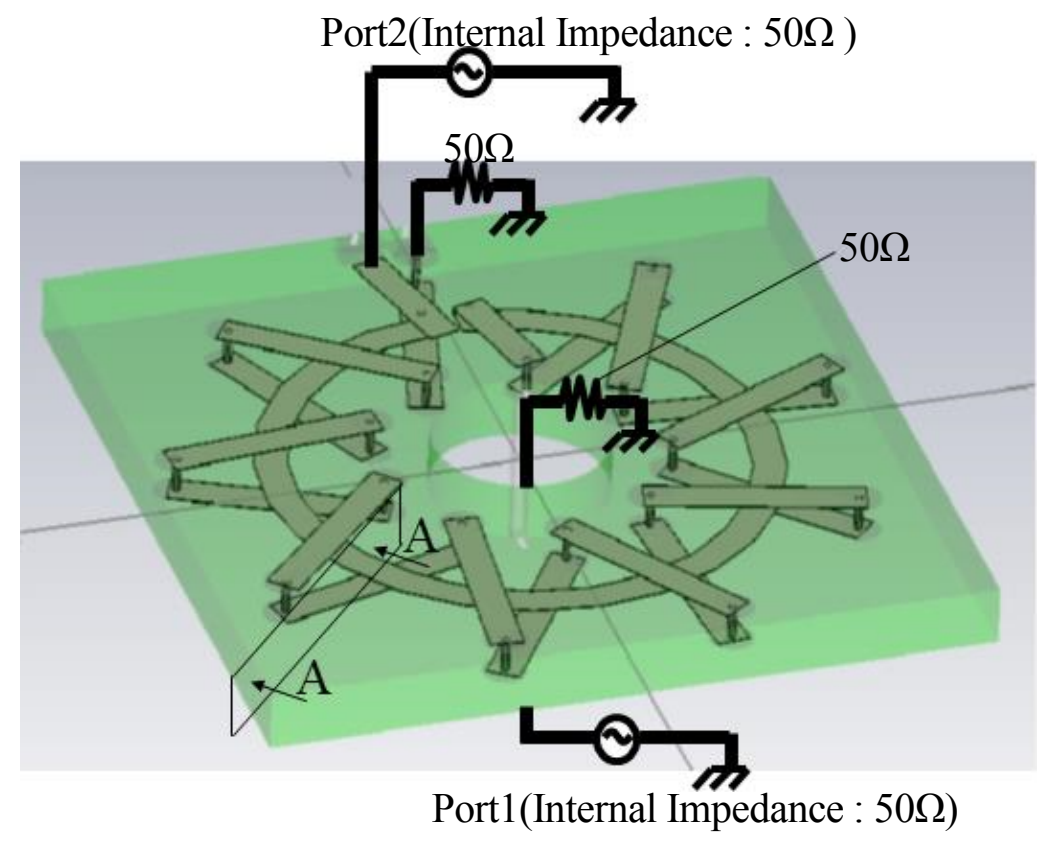

Fig. 3 Whole diagram of simulation 

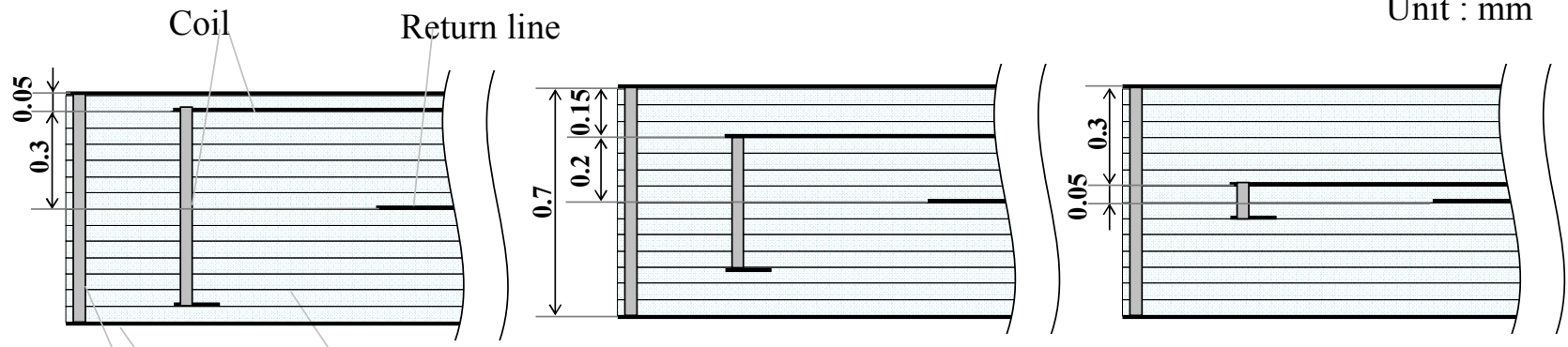

\begin{abstract}
Shield of Laminated PALAP electric field substrates

(14 layers)
\end{abstract}

(b)

(c)

Fig. 4 Cross section diagram of simulation

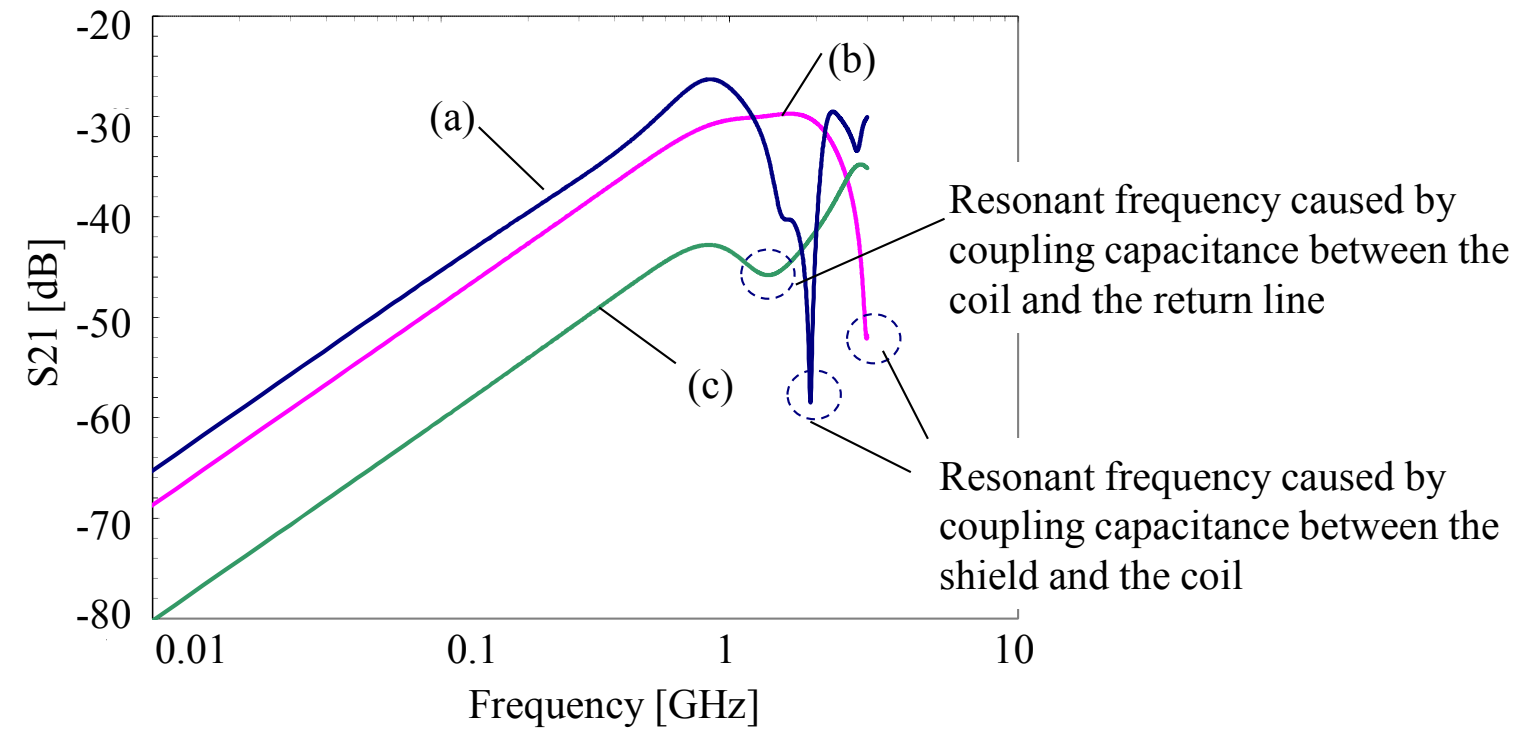

Fig. $5 S_{21}$ result of simulation when coil position changed

\section{$4 \cdot 2$ コイル線幅の検討}

上記(b)の構成において，コイル線幅の周波数特性への影響をシミュレーションにて検証し，最適となるコイル 線幅を検討した. コイル線幅を $0.2 \mathrm{~mm} \sim 0.6 \mathrm{~mm}$ と変えた時の $\mathrm{S}$ パラメータ通過特性 $\left(S_{21}\right)$ のシミュレーション結果を 図 6 に示寸.コイルの線幅を太くすると，コイルの自己インダクタンス L は小さくなるが，コイルとシールド面 の結合面積が大きくなり，結合容量 C が大きくなる.

コイル線幅 $0.2 \mathrm{~mm}$ 及び $0.4 \mathrm{~mm}$ においては，コイル線幅が細く，自己インダクタンス L が増大寸るためにコイル

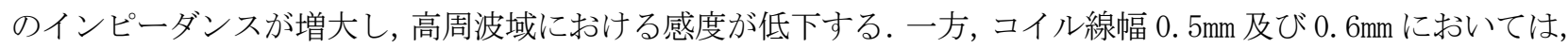
コイル線幅が太く，結合容量 C が増大寸るためにコイルのインピーダンスが低下し，高周波域における感度が増 大寸る. コイル線幅 $0.45 \mathrm{~mm}$ において, 感度の高周波数特性が最も高周波域まで比例関係を持っており, 最適な線 幅と考える. 


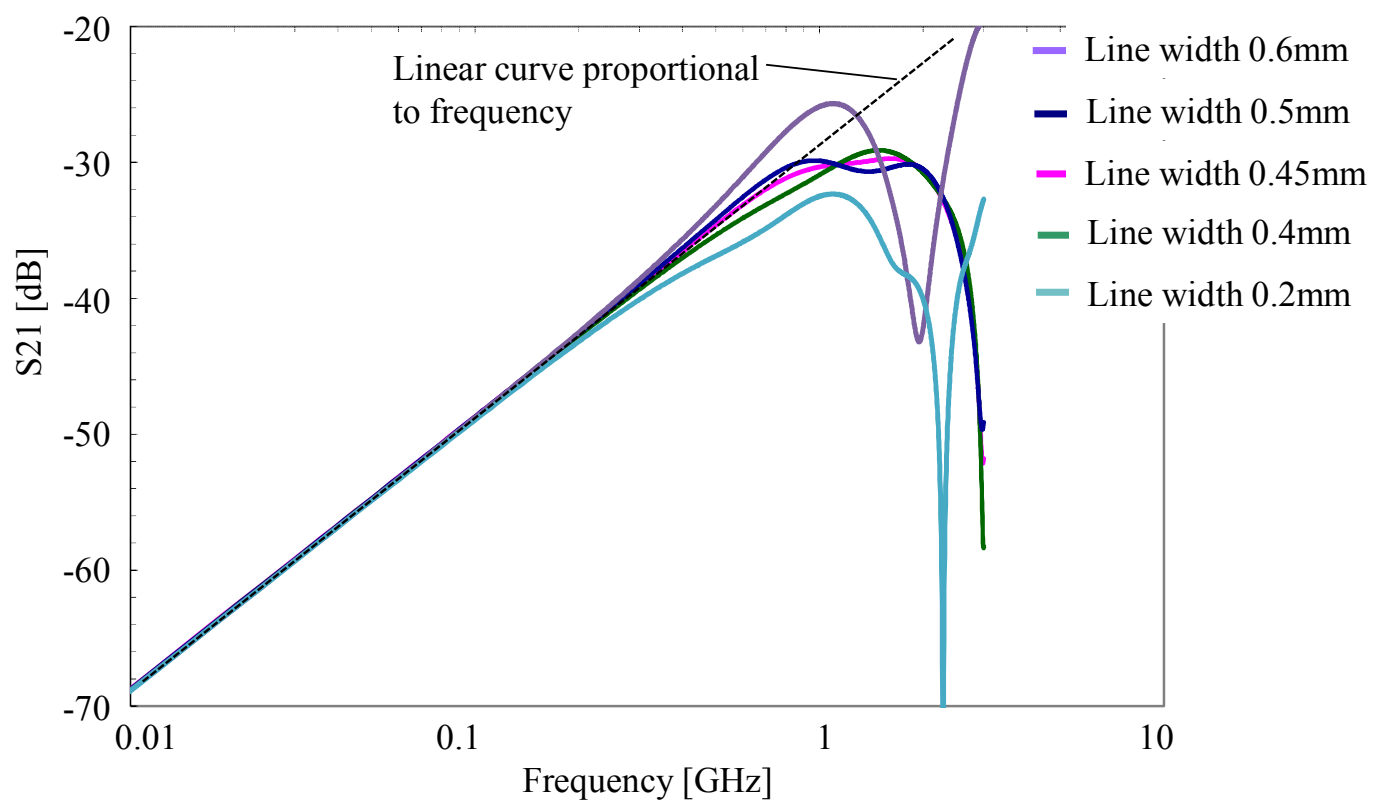

Fig. $6 S_{21}$ result of simulation when coil line width changed

\section{5. 積層基板型ロゴスキーコイルの試作・評価}

試作した積層基板型ロゴスキーコイル式電流センサの概観写真を図 7 に示寸.PALAP 基板 14 層の積層構造とし, 厚み $0.7 \mathrm{~mm}$ ，ロゴスキーコイル部のサイズが $10 \mathrm{~mm} \times 10 \mathrm{~mm}$ となっている. 戻り線側を $50 \Omega$ 終端，コイル側をオシ ロスコープに接続して計測する. ロゴスキーコイル部からの取り出し線はマイクロストリップライン構造によっ て特性インピーダンスが $50 \Omega$ となるよう設計している.

試作品の周波数特性を S パラメータ通過特性 $\left(s_{21}\right)$ にて実測評価した。測定構成を図 8 に示す。試作品評価用基 板として，試作したマイクロストリップライン基板を用いている. センサ挿入部として $2 \mathrm{~mm}$ のスリットを設けて おり，ロゴスキーコイルにバスバーを通してマイクロストリップライン基板に接続する構成で評価した.

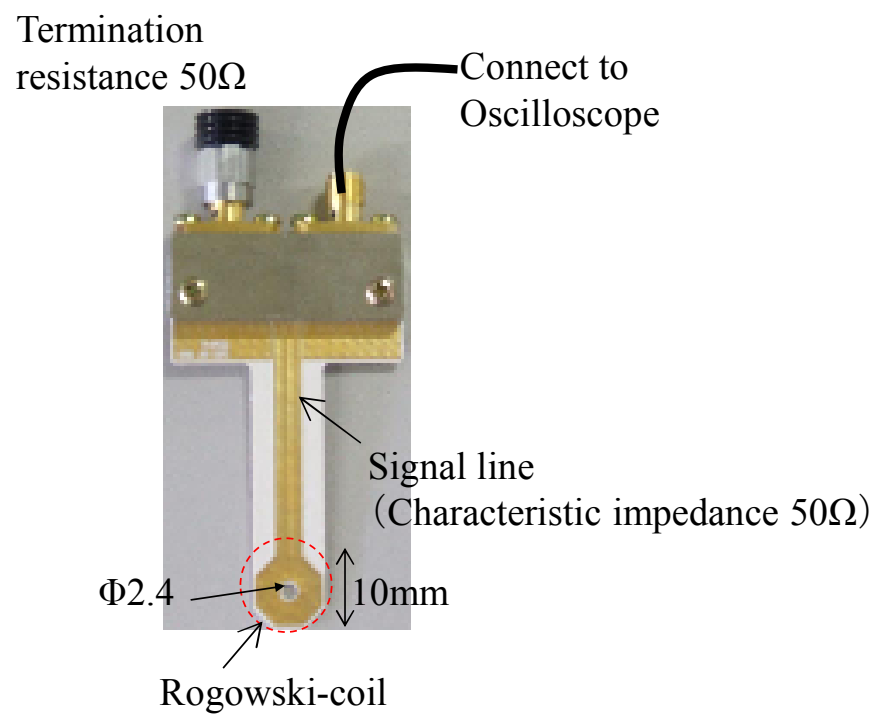

Fig. 7 Picture of Rogowski-coil prototype 


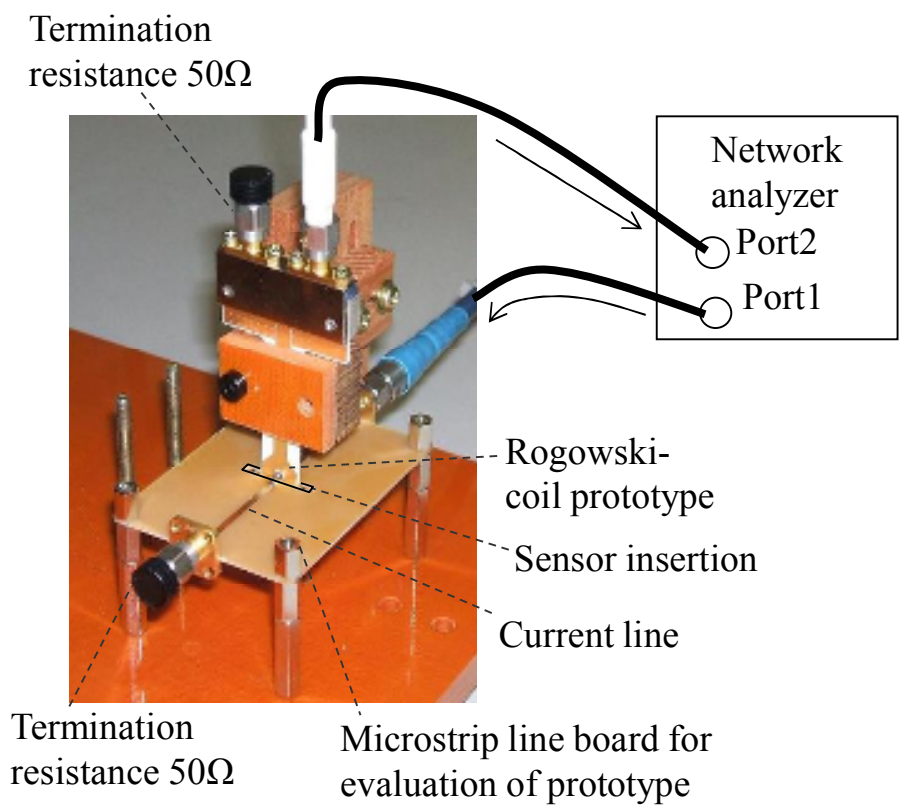

Fig. 8 Measurement composition of $S_{21}$ characteristics of Rogowski-coil

$\mathrm{S}$ パラメータ通過特性 $\left(S_{21}\right)$ の実測結果を図 9 に示す. 今回試作した PALAP 基板製の積層基板型ロゴスキーコイ ルでは，1.2 $\mathrm{GHz}$ まで良好な直線性 (誤差士5\%以内の周波数範囲)を持つことが確認でき，目標帯域とした $1 \mathrm{GHz}$ 以 上を達成している. 本試作品により, 市販の広帯域電流プローブ（ピアソン社製，2877）の周波数帯域 $200 \mathrm{MHz}$ では計測できない，帯域 $1.2 \mathrm{GHz}$ までの高周波電流がセンシング可能と考える. なお， $30 \mathrm{MHz}$ 以下の周波数帯では $\mathrm{S}$ パラメータ通過特性 $\left(S_{21}\right)$ の測定值にばらつきが見られるが, これは計測器の計測限界領域であり, ノイズフロア の影響を受けているためと考える.

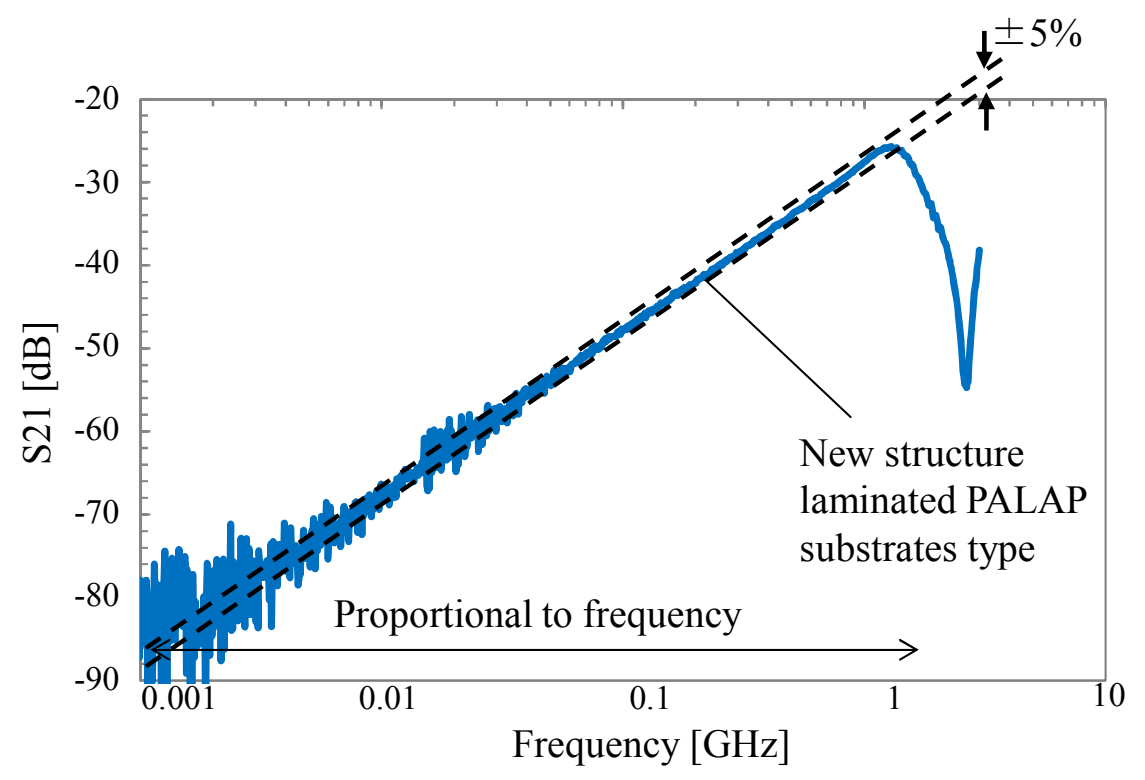

Fig. 9 Measurement result of $s_{21}$ characteristics 


\section{6. 結言}

本研究では, 電流センサへの応用を想定し, PALAP 基板を用いた積層基板構造の小型広帯域コイルを検討した. 電流センサのスペックとしてパワーエレクトロニクス回路のスイッチング時に発生する高周波リンギング電流を 高精度にセンシングする(周波数帯域 $1 \mathrm{GHz}$ ，センサ挿入部 $5 \mathrm{~mm}$ 以下)ことを考え, 高周波化, 薄型化を狙った積層 基板型広带域ロゴスキーコイルを開発した，基板については，高周波特性に優れた PALAP 基板を用いることを提 案し, 高帯域化のためのコイル構造として, コイルを形成する層と結合容量との関係，またコイル線幅と周波数 特性との関係をシミュレーション検討により，最適な高周波特性を持つコイル構造を決定した．積層基板型ロゴ スキーコイル試作により, 厚み $0.7 \mathrm{~mm}$, 帯域 $1.2 \mathrm{GHz}$ が得られることを明らかにした. また, 本研究で提案する積 層基板型コイルの応用展開として, 近年注目が高まるエネルギーハーベスト技術において, 電磁誘導型の振動発 電素子にも適用できると考える，電磁誘導型の振動発電素子ではコイルの体格が大きくなることが課題の一つと なっているため，小型コイルを適用し，また，整流回路などの周辺回路も一体化することで，素子および回路全 体の小型化が期待できると考える.

\section{文 献}

Hayashi, A., Nakagoshi, M., Murai, T., Sera, N., Ogihara, C., Oikawa, R., Suzuki, K., Kataoka, R. and Ozaki, Y., A new FCBGA packaging technology based on the PALAP process, The $7^{\text {th }}$ VLSI Packaging Workshop of Japan, Session 5.3(2004).

石山泰士，平型 IGBT 素子内部電流の測定，平成 14 年電気学会全国大会 4-010(2002).

伊藤秀夫，電子回路変成器，誠文堂新光社(1967), pp.31-65.

片岡良平，近藤宏司，鈴木克信，PALAP 基板による半導体パッケージ技術の開発，デンソーテクニカルレビュ 一Vol.10 No.2 (2005), pp.77-84.

木下隆博, 電気数学III, オーム社(1973), p.59.

Oates, C.D.M., Burnett, A.J. and James, C., The design of high performance Rogowskicoils, Proceedings of the International Conference on Power Electronics, Machines and Drives(2002), pp.568-573.

岡田章, 井上悟, プリント基板型ロゴスキコイル電流センサの開発，平成 14 年電気学会基礎・材料・共通部門 大会論文集(2002), p.431.

Qing, C., Hong-bin, L., Ming-ming, Z. and Yan-bin, L., Design and characteristics of two Rogowski coils based on printed circuit board, IEEE Transactions on Instrumentation and Measurement, Vol.55, No.3(2006), pp.939-943.

矢崎芳太郎，横地智宏，片岡良平，近藤宏司，鈴木克信，固層拡散接合を適用した PALAP 多層基板の開発，デ ンソーテクニカルレビューVol.10 No.2(2005), pp.85-89.

\section{References}

Hayashi, A., Nakagoshi, M., Murai, T., Sera, N., Ogihara, C., Oikawa, R., Suzuki, K., Kataoka, R. and Ozaki, Y., A new FCBGA packaging technology based on the PALAP process, The $7^{\text {th }}$ VLSI Packaging Workshop of Japan, Session 5.3(2004).

Ishiyama, Y., Mesurment of Current in flat-packaged IGBT device, The Institute of Electrical Engineers of Japan 4-010(2002) (in Japanese).

Ito, H., Electronic circuit transformer, Seibundo shinkosha(1967), pp.31-65 (in Japanese).

Kataoka, R., Kondo, K. and Suzuki, K., Semiconductor packaging technology based on the PALAP process, Denso technical review Vol.10 No.2 (2005), pp.77-84 (in Japanese).

Kinoshita, T., Electric mathematics, Ohmsha(1973), p.59 (in Japanese).

Oates, C.D.M., Burnett, A.J. and James, C., The design of high performance Rogowskicoils, Proceedings of the International Conference on Power Electronics, Machines and Drives(2002), pp.568-573.

Okada, A. and Inoue, S., Development of Rogowski coil current sensor using printed circuit board, Proceeding of Annual Conference of Fundamentals and Materials Society, IEE Japan(2002), p.431 (in Japanese).

Qing, C., Hong-bin, L., Ming-ming, Z. and Yan-bin, L., Design and characteristics of two Rogowski coils based on printed circuit board, IEEE Transactions on Instrumentation and Measurement, Vol.55, No.3(2006), pp.939-943.

Yazaki, Y., Yokochi, T., Kataoka, R., Kondo, K. and Suzuki, K., A new Sn/Ag sintering alloy diffusion bonding technology for the PALAP. process, Denso technical review Vol.10 No.2 (2005), pp.85-89 (in Japanese). 